\title{
DEGRADATION OF MONO-AZO DYE IN AQUEOUS SOLUTION USING CAST IRON FILINGS
}

\author{
Raja Kumar', Alok Sinha ${ }^{2}$ \\ ${ }^{1}$ Research Scholar, ${ }^{2}$ Assistant Professor, Department of Environmental Science and Engineering, Indian School of \\ Mines,Dhaanbad,aloksinha11@yahoo.com
}

\begin{abstract}
The mono-azo dye, Orange II, solution was substantially degraded with cast iron particles under varied conditions of experimental variables such as $\mathrm{pH}$, initial dye concentration and cast iron dosage.At all solution $\mathrm{pH}$ studied, the degradation efficiency achieved was > 90\%. With an initial dye concentration of $100 \mathrm{mg} / \mathrm{L}$ and optimum cast iron load of $28.56 \mathrm{~g} / \mathrm{L}$, the optimum degradation efficiency of $97.63 \%$ was achieved at $\mathrm{pH}$ 3. With same cast iron load and solution $\mathrm{pH}$, more than $95 \%$ dye degradation efficiency was achieved at different initial Orange II concentrations ranging from 50-500 $\mathrm{mg} / \mathrm{L}$. The efficiency of cast iron particles in degrading Orange II dye was compared with that of pure elemental iron used in other study. Cast iron particles showed better degradation efficiencies than elemental iron that too at relatively lower dosages. Ultimately, from the results it can be inferred that cast iron fillings can be successfully applied to treat textile effluents containing high dye concentration and treatment efficiency can be enhanced by optimizing the reaction conditions.
\end{abstract}

Index Terms: azo dyes, Orange II, degradation efficiency, cast iron fillings

\section{INTRODUCTION}

Textile dyeing industries have long been one of the most important industries in the world. According to an estimate, around 0.7 million tons of dye are used every year of which $50 \%$ are azo dyes [1]. Of the total dye produced, $15 \%$ is lost during the dyeing process [2]. Dyes being tinctorially stronger are visible in water at concentrations as low as $1 \mathrm{ppm}$ [3]. Available literatures points that dye containing effluent are more mutagenic and toxic when compared to other industrial discharges [4]. Researchers have shown that azo dyes released into ground and surface waters from textile discharges contribute to mutagenic activity [5,6]. Besides, the release of coloured wastewater in the ecosystem is a remarkable source of aesthetic pollution, eutrophication, and perturbations in aquatic life [2].Several chemicals found in dye-bath effluent are toxic, carcinogenic, mutagenic, or teratogenic to various life forms. The human health impact of dyes, especially azo dyes and their degradation products have caused concern for a number of years, with legislation controlling their use, being developed in a variety of countries [7]. Increasingly, the environment and subsequent health effects of azo dyes released in textile industry wastewater are becoming subject to scientific scrutiny. It is hence not surprising that removal of these compounds has now-a-days become a major environmental concern.

Many physical and chemical treatment processes have been developed in scientific laboratory but their practical applicability is restricted either by cost or efficiency and cannot be adopted as an exclusive method.Conventional biological treatment methods alone generally are ineffective insofar as complete azo dye degradation is concerned[8]. Since biological treatment methods are still the cheapest option available, efforts should be made to develop an effective pretreatment technology that could transform the azo dyes into easily bio-decomposable compounds.

Reductive transformation of pollutants using cast iron filings is widely gaining attention for environmental remediation. Cast iron filings are cheap and easily available strong reducing agent. The literature substantially reports the applicability of cast iron filings in treating wastewater contaminated with chlorinated compounds [9], nitroaromatic compounds [10], heavy metals [11], explosives[12] and dyes[13], etc. Among these pollutants azo dyes are considered as most susceptible to metallic reduction [14], thus, if the treatment conditions are optimized cast iron filings can serve as an effective pretreatment alternative. In this study, treatment of synthetic wastewater containing mono-azo dye Orange II has been carried out using cast iron filings. This study intends to optimize the key reaction parameters that could affect the applicability of cast iron filings for treating azo dye-containing wastewater in large scale.

\section{MATERIALS AND METHODS}

\subsection{Dye}

Commercially available mono-azo dye Orange II (M.W.350.32 )which is a widely used anionic monoazo-dye [15] was 
chosen as a model of the hydro soluble phenylazonaphthol dyes due to its resistance to biological degradation.AO7 was purchased from Atul Ltd. (India) and was used as received. The dye solutions in a $1 \mathrm{~cm}$ quartz cuvette were scanned over the wavelength range $200-800 \mathrm{~nm}$ using a UV-visible spectrophotometer (UV-1800 series, Shimadzu, Japan) for determination of the wavelength of maximum absorbance $(\lambda$ $\max )$.

\subsection{Preparation of Cast Iron Fillings}

Commercially available cast iron rod was chipped on a lathe machine and then ground into iron filings in a dough-size ball mill. The filings were sieved and those between $40(425 \mu \mathrm{m})$ and $80(212 \mu \mathrm{m})$ mesh sizes were retained for use. Cast iron fillings, thus produced, was washed 5-6 times with N2-sparged $1 \mathrm{~N} \mathrm{HCl}$ with periodic shaking. Then it was rinsed 10-12 times with N2-sparged deionised (Milli Q) water. The washed fillings were rinsed twice with acetone to remove moisture. Again it was rinsed twice with $95 \%$ pure ethanol and dried for 1 hour. This treatment yielded black metallic filings with no visible rust on the surface. Fillings were stored in a vacuum desiccator until use in various experiments.Surface area of the treated filings was determined by BET (N2) analysis using a BET surface area analyzer (NOVA 4000e, Quanta chrome Instruments, USA) to be $1.4 \mathrm{~m} 2 / \mathrm{g}$.

\subsection{Experimental Procedure}

Time series batch experiments were carried out in $35 \mathrm{ml}$ capacity glass vials with screw caps (Borosil, India). All dye solutions were prepared using deionized (Milli Q) water and all reagents utilized were of analytical purity. The solution $\mathrm{pH}$ was adjusted to the desired levels using $\mathrm{HCl}(0.5 \mathrm{M})$ or $\mathrm{NaOH}$ $(0.1 \mathrm{M})$ with a $\mathrm{pH}$ meter (Digital $\mathrm{pH}$ meter 111 , EI, India). For proper mixing, the vials were placed on a test tube rotator (Rotospin, Tarsons, India), at $30 \mathrm{rpm}$, keeping the axis of vials horizontal. Temperature was $25 \pm 2 \circ \mathrm{C}$ for all experiments.

Vials were removed from the rotator in duplicate (along with a control) at specified times for sampling and analysis and were put on a magnet to allow iron particles to settle down quickly. Supernatant samples were taken out from vials and filtered through GF/C filter paper $(1.2 \mu \mathrm{m}$ nominal pore size, What man, Springfield Mill, England).

\subsection{Analytical Procedure}

Efficiency of cast iron fillings for the degradation of Orange II was assessed in terms of decolorization efficiency (\%) as follows:

Degradation efficiency $(\%)=\left[1-\mathrm{A}_{\mathrm{t}} / \mathrm{A}_{0}\right] \times 100 \%$

Where At $=$ absorbance of solution at time ' $t$ ' of treatment,

$\mathrm{A} 0=$ absorbance of untreated solution.

\subsection{RESULTS \& DISCUSSION}

\subsection{UV-Vis Scan}

The UV-vis spectra of Orange II scanned over wavelength range of 200 to $800 \mathrm{~nm}$ is shown in Fig.1. Different absorbance peaks exhibit different structural units and groups of the dye molecule.Orange II is characterized by one main band in visible region, with its maximum absorption at 484 $\mathrm{nm}$, and two bands in ultraviolet region located at $229 \mathrm{~nm}$ and $310.5 \mathrm{~nm}$. These observed peaks correspond to chromophore containing azo linkage, benzene ring and naphthalene ring, respectively [16].

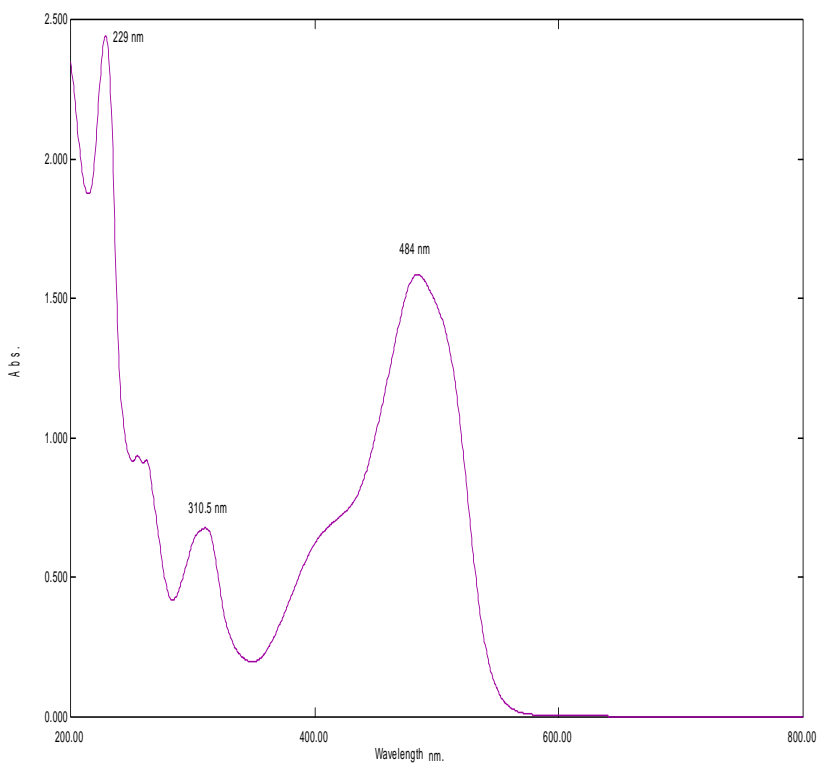

Fig.1: UV-Vis spectra of Orange II azo dye

\subsection{Effect of Solution pH}

Solution $\mathrm{pH}$ has been considered as one of the important factors in governing the reduction of contaminants by elemental iron, therefore the effect of initial solution $\mathrm{pH}$ on the decolorization of Orange II was studied, and the results are shown in Fig.2. The degradation efficiency crossed more than $90 \%$ within $5 \mathrm{~min}$ of treatment.Final Orange II degradation efficiency after $60 \mathrm{~min}$ of treatment was $97.63 \%, 97.11 \%$, $96.97 \%, 95.14 \%, 93.95 \%$, for $\mathrm{pH} 3, \mathrm{pH} 4, \mathrm{pH} 5, \mathrm{pH} 6$ and $\mathrm{pH}$ 7 , respectively. As the solution $\mathrm{pH}$ increased decolorization efficiency decreased.When dye molecule collides with elemental iron, elemental iron, as an electron donor, loses electrons, the dye molecule, as an electron acceptor, accepts electrons, and combines with $\mathrm{H}+$ to form a transitional product. This product receives electrons from elemental iron and combines with $\mathrm{H}+$ again, finally turning into terminal products. With more $\mathrm{H}+$ in acid solution than that in alkaline solution, the reaction in acid solution is easier [17]. 


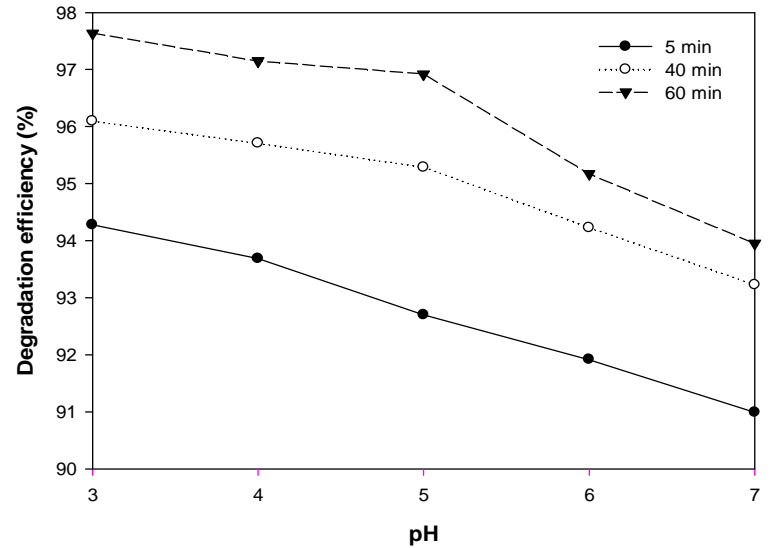

Fig.2: Effect of different $\mathrm{pH}$ values on degradation of Orange II dye solution (Initial conditions:cast iron dose $=$ 28.56g/Ll;Orange II conc.=100 mg/L; mixing speed-30 rpm)

\subsection{Effect of Initial Dye Concentration}

The effect of initial concentrations of Orange II on its degradation efficiency were evaluated at a concentration range of $50 \mathrm{mg} / \mathrm{L}$ to $500 \mathrm{mg} / \mathrm{L}$ using $28.56 \mathrm{mg} / \mathrm{L}$ cast iron dosage at $\mathrm{pH}$ 3. As shown in Fig. 3, the degradation efficiencies achieved after 5 min was decreasing with increasing initial Orange II concentration, i.e., 97.21, 94.81, 92.48,75.18, 57.07 and $47.63 \%$ for initial dye concentrations of $50 \mathrm{mg} / \mathrm{L}, 100$ $\mathrm{mg} / \mathrm{L}, 200 \mathrm{mg} / \mathrm{L}, 300 \mathrm{mg} / \mathrm{L}, 400 \mathrm{mg} / \mathrm{L}$ and $500 \mathrm{mg} / \mathrm{L}$, respectively. This suggests that the decolorization is adsorption controlled process [18]. The final efficiencies were greater than $95 \%$ after $60 \mathrm{~min}$ of treatment for all concentrations of Orange II studied.

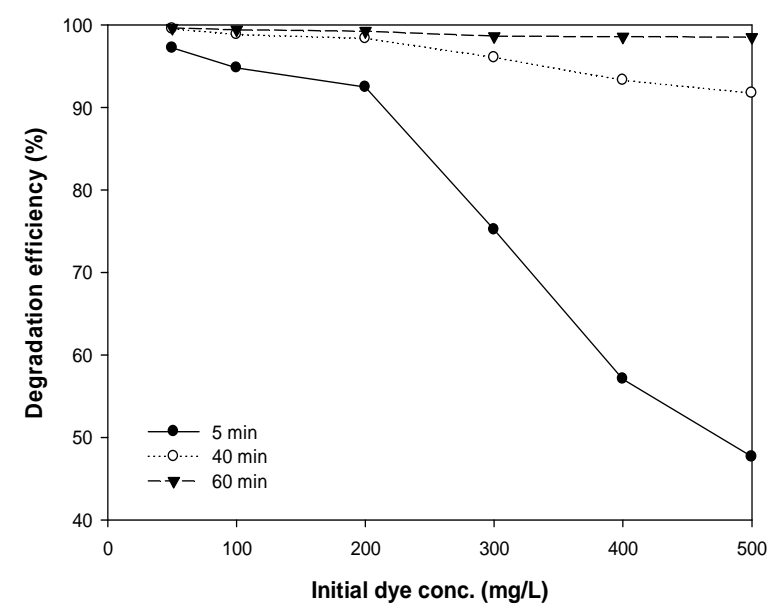

Fig. 3: Effect of different initial dye concentration on degradation of Orange II dye solution (Initial conditions: cast iron dose $=28.56 \mathrm{~g} / \mathrm{L} ; \mathrm{pH}-3.00$; mixing speed $-30 \mathrm{rpm}$ )

\subsection{Effect of Cast Iron Load}

The effect of the cast iron dosage on on Orange II removal efficiency,shown in Fig. 4, indicates that Orange II degradation efficiency increased with the increase of the cast iron load. From the experimental data $54.93 \%, 75.13 \%$, $96.25 \%, 96.79 \%$ and $96.91 \%$ degradation efficiencies within first $5 \mathrm{~min}$, and96.36, 97.63, 99.42, 99.21 and 99.21\%after 60 min by cast iron doses of $7.14 \mathrm{~g} / 1,14.28 \mathrm{~g} / \mathrm{l}, 28.56 \mathrm{~g} / \mathrm{l}, 42.84 \mathrm{~g} / \mathrm{l}$ and $57.12 \mathrm{~g} / \mathrm{l}$, respectively. Increasing the load of cast iron provided substantially more active surface sites to accelerate the initial reaction, resulting in more iron surface collision with more azo dye molecules to enhance Orange II degradation. However, highest degradation efficiency was achieved at cast iron dosage of $28.56 \mathrm{~g} / \mathrm{L}$. This unusual precept can be attributed to the fact that the presence of excessive iron in the acidic solution system could be detrimental since the final $\mathrm{pH}$ of the system could reach higher values thereby decreasing the degradation rate [19].

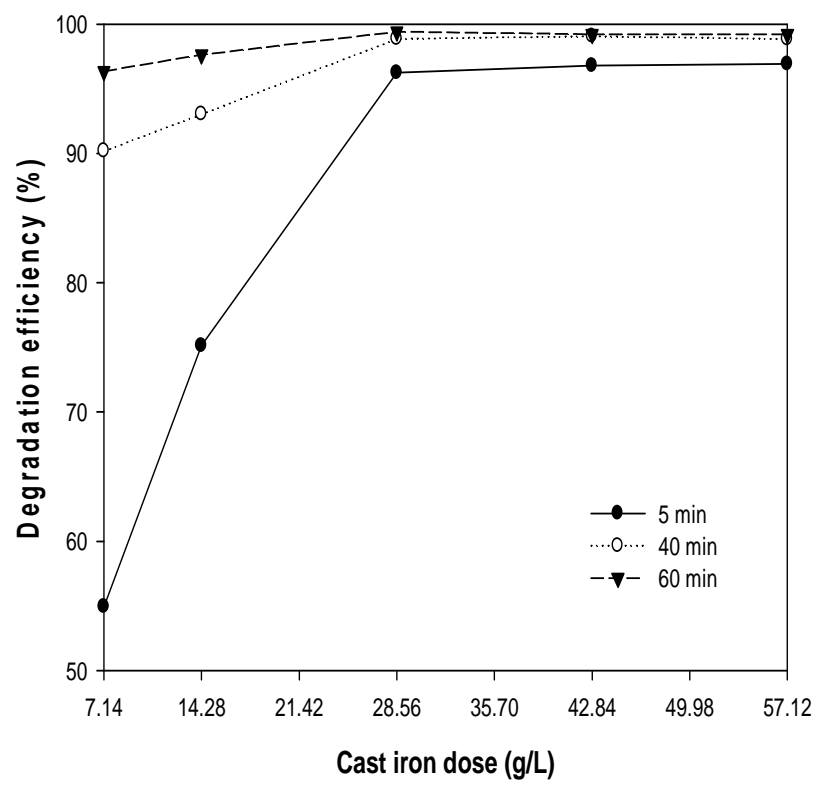

Fig. 4: Effect of different cast iron dosage on degradation of Orange II dye solution (Initial conditions: solution $\mathrm{pH}-3$; Orange II conc. $=100 \mathrm{mg} / \mathrm{L}$; mixing speed $-30 \mathrm{rpm}$ )

\subsection{Comparison of Efficiencies of Cast Iron Fillings and Pure Iron}

Table 1 shows the comparative degradation efficiencies of Orange II using pure elemental iron as reported by $\mathrm{Mu}$ et al.[18], and cast iron fillings reported in this work. $\mathrm{Mu}$ et al.[18] have reported highest degradation efficiency of $90-95 \%$ for $101.5 \mathrm{mg} / \mathrm{L}$ Orange II adding $66.6 \mathrm{~g} / \mathrm{L}$ of pure iron after 80 min of reaction time. Whereas in this study greater than $99 \%$ 
degradation efficiency could be achieved for $100 \mathrm{mg} / \mathrm{L}$ Orange II using fairly low cast iron loading of $28.56 \mathrm{~g} / \mathrm{L}$ within 60 min of reaction time. Also, the mixing speed was kept 4 times lower at $30 \mathrm{rpm}$ in this study compared to $120 \mathrm{rpm}$ reported by $\mathrm{Mu}$ et al.[18]. In addition, cast iron fillings showed significantly higher degradation efficiencies at all $\mathrm{pH}$ ranges studied. This greater ability of cast iron to degrade Orange II could be attributed to the presence of graphite inclusions embedded in the iron matrix which serves as anon-reactive adsorption site[9,20,21]. Thus, adsorption and reduction takes place simultaneously on cast iron surface.

Table 1: Comparison of degradation efficiency of cast iron and zero valent iron studies

\begin{tabular}{|c|c|c|c|c|c|c|c|c|c|}
\hline Author & Iron type & $\begin{array}{c}\text { Dosage } \\
(\mathrm{g} / \mathrm{L})\end{array}$ & Dye & $\begin{array}{c}\text { Mixing } \\
\text { rate } \\
(\text { rpm })\end{array}$ & $\operatorname{Temp}\left({ }^{\circ} \mathbf{C}\right)$ & $\begin{array}{c}\text { Reaction } \\
\text { time } \\
\text { (min) }\end{array}$ & $\begin{array}{l}\text { Conc. } \\
\text { (mg/L) }\end{array}$ & pH & Efficiency (\%) \\
\hline $\begin{array}{l}\text { Mu et } \\
\text { al.[18] }\end{array}$ & Micro-ZVI & 66.6 & Orange II & 120 & 30 & 80 & $\begin{array}{c}49 \\
101.5 \\
199.5 \\
101.5 \\
101.5 \\
101.5 \\
101.5\end{array}$ & $\begin{array}{l}4 \\
4 \\
4 \\
3 \\
5 \\
6 \\
7\end{array}$ & $\begin{array}{c}<90 \\
\sim 75 \\
75 \\
90-95 \\
70 \\
60-70 \\
60\end{array}$ \\
\hline $\begin{array}{l}\text { This } \\
\text { work }\end{array}$ & $\begin{array}{l}\text { Micron } \\
\text { sized Cast } \\
\text { Iron }\end{array}$ & 28.56 & Orange II & 30 & $25 \pm 2$ & 60 & $\begin{array}{c}50 \\
100 \\
200 \\
100 \\
100 \\
100 \\
100\end{array}$ & $\begin{array}{l}3 \\
3 \\
3 \\
4 \\
5 \\
6 \\
7\end{array}$ & $\begin{array}{c}>99 \\
>99 \\
>99 \\
97 \\
\sim 97 \\
95 \\
\sim 94\end{array}$ \\
\hline
\end{tabular}

\section{CONCLUSIONS}

In this work, the parameters affecting the reductive degradation of Orange II dye were investigated. Although cast iron particles were found to be capable of degrading more than $90 \%$ of Orange II at all $\mathrm{pH}$ examined within $5 \mathrm{~min}$ of treatment time, optimum degradation efficiency of $97.63 \%$ was achieved at pH 3 after $60 \mathrm{~min}$. More than $50 \%$ dye degradation was achieved at all cast iron dosages within $5 \mathrm{~min}$ and the efficiencies exceeded $90 \%$ at all dosages after $40 \mathrm{~min}$. At all the initial Orange II dye concentration studied, more than $95 \%$ degradation efficiencies could be achieved using cast iron dosage of $28.56 \mathrm{~g} / \mathrm{L}$. This indicates that cast iron can be effective even at the wide range of dye concentration in textile effluent. Comparative assessment of degradation efficiencies of cast iron and pure elemental iron reveals greater capability of cast iron to treat dye containing wastewater.Apart from the experimental results, the fact that cast iron is available at a fraction of the cost of the high purity iron makes it a more ideal cost effective alternative for practical treatment applications.

\section{ACKNOWLEDGEMENTS}

The authors heartily acknowledge Technical Education Quality Improvement Programme Phase II (TEQIP II), ISM, Dhanbad, for providing all necessary assistance for completion of this research work.

\section{REFERENCES}

[1] Zhao W, Wu Z, Shi,H, Wang D. UV photodegradation of azo dye diacryl red X-GRL. J PhotochemPhotobiolA 2005; 171:97.

[2] Gemeay AH, Mansour IA, El-Sharkawy RG, and Zaki AB. Kinetics and mechanism of the heterogeneous catalyzed oxidative degradation of indigo carmine. J. Mol. Catal. A: Chemical 2003; 193:109.

[3] Pandey A Singh P and Iyengar L. Bacterial decolorization and degradation of azo dyes (a review). Int. Biodeter. Biodegr 2007;59: 73-84.

[4] Houk VS. The genotoxicity of industrial wastes and effluents- A review. Mutat Res 1992; 277: 91-138. 
[5] Rajaguru P, Vidya L, Baskarasethupathi B, Kumar PA, Palanivel $\mathrm{M}$ and Kalaiselvi K. Genotoxicity evaluation of polluted ground water in human peripheral blood lymphocytes using the comet assay. Mutat Res 2002; 517: 29-37.

[6] De AragaoUmbuzeiro G, Freeman HS, Warren SH, de Oliveira DP, Terao Y, Watanabe T, and Claxton LD . The contribution of azo dyes to the mutagenic activity of the Cristais River. Chemosphere 2005; 60: 55-64.

[7] Hildenbrand, S, Schmahl FW, Wodarz R, Kimmel R, Dartsch PC. Azo dyes and carcinogenic aromatic amines in cell culture. Jr. of Int Arch Occup Environ Health 1999; 72 (3):52-56.

[8] Singh K \&Arora S. Removal of Synthetic Textile Dyes From Wastewaters: A Critical Review on Present Treatment Technologies. Critical Reviews in Environ Sci\&Technol. 2011; 41:807-878.

[9] Sinha A, Bose P. Interaction of 2-chloronaphthalene with high carbon iron filings (HCIF): Adsorption, dehalogenation and mass transfer limitations. J Colloid \& Interface Sci2007; 314:552-561.

[10] Dong J, Zhao Y, Zhao R, Zhou R. Effects of $\mathrm{pH}$ and particle size on kinetics of nitrobenzene reduction by zero-valent iron. J Environ Sci 2010; 22(11):17411747.

[11] Wanner C, Eggenberger U, Mäder V. Reactive transport modelling of $\mathrm{Cr}(\mathrm{VI})$ treatment by cast iron under fast flow conditions. App Geochem 2011; 26:1513-1523.

[12] Oh SY, Chiu PC, Kim BJ, Cha DK. Enhancing Fenton oxidation of TNT and RDX through pretreatment with zero-valent iron. Water Res. 2003; 37:4275-4283.

[13] Shen Z, Shen J. The use of ultrasound to enhance the degradation of the Basic Green by cast iron. J Environ Sci 2006; 18(1):1-3.

[14] Zhao Z, Liu J, Tai C, Zhou Q, Hu J \& Jiang G. Rapid decolorization of water soluble azo-dyes by nanosized zero-valent iron immobilized on the exchange resin. Sci China Ser B-Chem 2008; 51(2):186-192.

[15] Zollinger H. Color Chemistry: Synthesis, Properties and Applications of organic dyes and pigments. New York: VCH publishers; 1991.

[16] Yang J (Ed.). Analysis of Dye. Beijing: Chemical Industry Press; 1987, p.156-163.

[17] Cao J, Wei L, Huang Q, Wang L, Han S. Reducing degradation of azo dye by zero-valent iron in aqueous solution. Chemosphere 1999; 38:565-571.

[18] Mu Y, Yu H-Q, Zhang S, Zheng J-C. Kinetics of reductive degradation of Orange II in aqueous solution by zero-valent iron. J Chem Tech Biotech 2004; 79:1429-1431.

[19] Devi LG, Kumar SG, Reddy KM, Munikrishnappa C. Photo degradation of Methyl Orange an azo dye by
Advanced Fenton Process using zero valent metallic iron: Influence of various reaction parameters and its degradation mechanism. J Hazard Mat 2009; 164:459-467.

[20] Burris DR, Allen-King RM, Manoranjan VS, Campbell TJ, Loraine GA, Deng B. Chlorinated ethene reduction by Cast iron: Sorption and Mass transfer. J Environ Eng 1998; 124(10):1012-1019.

[21] Sinha A, Bose P. Interaction of 2, 4, 6trichlorophenol with high carbon iron filings: Reaction and sorption mechanisms. J Hazard Mat 2009; 164:301-309. 